\title{
Analyzing Indian Policies and Firm Strategies in Africa
}

\author{
Kinfu Adisu \\ Grand Valley State University, Grand Rapids, USA \\ Thomas W. Sharkey \\ College of Business and Innovation, University of Toledo, Toledo, Ohio, USA \\ Sam C. Okoroafo \\ College of Business and Innovation, University of Toledo, Toledo, Ohio USA \\ Tel: 1-419-530-4398_E-mail: sam.okoroafo@utoledo.edu
}

Received: April 8, 2013 Accepted: April 23, 2013 Published: July 1, 2013

doi:10.5296/jmr.v5i3.3499

URL: http://dx.doi.org/10.5296/jmr.v5i3.3499

\begin{abstract}
This paper investigates Indian's policy and Indian firms' strategic presence in Africa. Recognizing the historical link between the two entities, our examination show that foreign investment outlays to Africa are sustainable. Further examination using foreign direct investment (FDI) and Porter's Competitive Advantage theories suggest some advantages enjoyed by Indian firms therein. Three publicly listed Indian companies- Tata Group, Bharti Enterprises, and Reliance have made extensive use of strategic alliances to penetrate and quickly accelerate activities.
\end{abstract}

Keywords: India, Africa, Investments, Alliances, Policy 


\section{Introduction}

Africa is moving beyond the point of simply being seen as a source of natural resources and is becoming a hub of high growth markets. These rapidly emerging markets are becoming very attractive to governments and businesses, particularly those of India (UNCTAD 2007).

India shares a long and important history with Africa. In ancient and medieval times, geographical proximity enabled these countries to have a shared history of cultural and trade exchanges. During the $20^{\text {th }}$ century, both shared common historical ties in their struggle for independence from the British and other European colonial rulers. India's links with the struggle for freedom and justice in South Africa dates back to the period during which Mahatma Gandhi started his Satyagraha movement in South Africa. India was at the forefront of the international community in its support to the anti-apartheid movement. And today, Africa continues to be an integral part of India's burgeoning economic growth.

\subsection{India's Africa policy}

India is developing into a free market economy through economic liberalization, including industrial deregulation, privatization of state-owned enterprises, and reduced controls on foreign trade and investment. This began in the early 1990s and has served to accelerate the country's growth, averaging more than 7\% per year since 1997 (CIA, 2011). In 2011, Indian investment flows into Africa topped US\$ 2.5 billion (UNCTAD 2013, p7). Accordingly, India-Africa trade is expected to top US\$90 billion by 2015 (Baynton-Glen 2012). Though India has been investing in resource extraction and new markets in Africa, its engagement on the continent did not attract as much attention (Kragelund, 2010) as Chinese investment (Edwards and Jenkins 2006). China's entry into Africa was controversial both for African countries (Haglund 2008) and the West, while India's engagement has been much quieter over the decades but is now gradually gaining substantial momentum. Currently, India's investment in Africa ranks $2^{\text {nd }}$ among the BRICS (Brazil, Russia, India, China, and South Africa) nations (UNCTAD 2013; Kimenyi and Lewis 2011).

The historical tie between India and African countries, particularly in eastern and southern Africa dates back centuries and has only strengthened since India's independence in 1947 (Kragelund, 2010; Broadman, 2008). Mahatma Gandhi, one of the key figures in the Indian independence movement, led the antiapartheid movement in Africa during the $19^{\text {th }}$ century. He arrived in South Africa in 1893 and experienced racism against Indians and native Africans, which inspired him to get personally involved in the South African movement (Kragelund, 2010). Quite often, Indian politicians emphasized their solidarity with the struggle for African independence, especially under the leadership of Jawaharlal Nehru, the founder of the 1955 Bandung Conference, which led to the Non-Alignment Movement (NAM). India and the majority of African nations stayed strong allies in the NAM movement. Cooperation between India and African countries grew closer in the late 1960s and early 1970s (Kragelund, 2010). In the 1970s and 1980s, India continued to support liberation struggles in Africa. It worked closely with Africans in the fight against apartheid in South Africa and Namibia; not just at the UN, but also with other multilateral institutions such as NAM, and in the Commonwealth. 
In this post-Cold War era, after the liberalization of Indian economic policies in 1991, Indians and Africans no longer remained just allies in the struggle against colonialism and apartheid. Indian government's agenda and the ambitions of the private sector began to take shape resulting in strategic interest in Africa (Mawdsley and McCann, 2010). According to Modi and Shekhawat (2009), there has been a noticeable change in Indian policy towards Africa since early 1990s. India's Africa policy in the post-Cold War era, it appears, is composed of five objectives: promoting economic cooperation, engaging the persons of Indian origin in Africa, preventing and combating terrorism, preserving peace and assisting African defense forces. [1]

\subsection{Why is Africa important to India?}

Beri (2005), in his strategic analysis of India's energy needs and Africa's potential resource base, acknowledged that energy security is potentially the biggest challenge for Indian policy makers in the coming decades. According to his study, India is one of the fastest growing consumers of energy in Asia. As its homegrown energy production diminishes against the burgeoning domestic demand, India will be forced to import $90 \%$ of much-needed crude oil and natural gas. Beri's explanation takes into consideration the following important factors: (i) Africa's potential: according to some estimates Africa has up to 24 billion barrels of oil reserves, and the production in Sub-Saharan Africa is projected to be 9 million barrels per day by 2030. (ii) India's energy security: while the economy is predicted to grow by 7-8\% over the next decade, it is ranked as sixth in the world in energy demand and consumption could increase faster than 5\% a year. (iii) Finally, the main reason for India's attraction comes from the high quality, low sulfur offshore oil production away from the conflict zones with an open market to foreign participation. This is unlike that of Gulf countries. And the fact that most of these African countries are not members of OPEC, which sets limits on output levels, is an added attraction.

Another important reason for interest in Africa is fueled by the population growth in most Asian countries. An increase in higher income strata with plentiful disposable incomes is spurring investments in Africa, both by individuals and Indian companies (Nevin, 2008). According to Pal (2008) there has been a massive increase in overseas investment, from US\$556 million in 1996-97 to more than US\$11 billion in 2006-07 in which he listed the following possible drivers: market access, transfer of technology, new product mix, location advantage, and securing access to raw material. This new trend can be viewed either positively as South-South cooperation or as exploitation similar to the actions of some multinationals from other countries.

While investing in natural resources is a common point of entry for all investors in Africa, India's on-ground reality is different from other counties and their companies. According to Broadman (2010), new firm-level data from Indian multinationals in Africa indicate diversified investment including: telecommunications, financial services, food processing, infrastructure and tourism. An Indian company in Africa can be of various sizes, mostly privately owned or in some cases mixed private-public ownership. Indian firms enter African markets mostly through acquisition of established business. 
Also, India's interest in African nations as huge export markets persists. Despite several initiatives to boost trade and economic and business cooperation by organizations like the Confederation of Indian Industries (CII), The Associated Chambers of Commerce and Industry (ASSOCHAM), the Federation of Indian Chambers of Commerce and Industry (FICCI) and the Federation of Indian Exporters' Organization (FIEO), exports to Africa are recognized as sub-optimal and have a wide potential to increase. The possibility of exporting generic AIDS drugs and IT systems exports to Africa are promising. [1]

\section{India's Policies and Firms Strategies}

\subsection{India's role in the emerging world order}

In broad terms, India is refocusing its foreign policy to meet new world realities, specifically towards Africa. This refocusing according to Desai (2009) is based on the following reasons: first, Africa is within the strategic and geopolitical realm of India, which makes it very important to collaborate with African countries, so India can maintain peace in the Indian Ocean to promote trade and deal with security concerns; second, cooperation with fifty-four African nations will bring more political clout in the UN, allowing the group to emerge as an effective voice on vital multilateral issues like climate change and international trade; third, other than as a source for oil and minerals, economically developed Africa could become an important market for India's goods and services; and finally, the presence of Indian diaspora should not underestimated, as a source for enhancing India-Africa cooperation. As Price (2004) explains, the policy changes under the National Democratic Alliance are intended to reinforce Indian political and economic interest benefiting Indian corporations and the government's global clout.

In a similar discussion of India's role in the emerging world order, Bava (2007) presents India's nuclear testing in 1998 as an important milestone that changed the way it is perceived. While India is still moving through the economic transition to become a developed country, its performance in soft infrastructure and growth in IT sector has dramatically changed the perception of Indian economy. Politically, India is viewed as a responsible nuclear nation and has successfully built a democratic society.

\subsection{India's private sector engagement}

According to Henley et al. (2008), Indian-owned companies operating in Sub-Saharan Africa have unique characteristics such that most of them are stand alone, owner-managed and are on average much smaller than Chinese firms. Despite their size, the number of Indian firms trading in Africa and their geographic distribution is increasing. In reference to the diversity of Indian firms, Banergee (2009) states that there are over 42 top level companies in Africa including companies like, Tata Group, Mahindras, Ashok Leyland, Essar, NIIT, and Marico with advanced products including: automobiles, telecommunications, IT training, and pharmaceuticals. This has encouraged trade between India and Africa boosting it from US\$3.39 billion in 2000 to US\$30 billion (dollars) for the year 2007; it is also estimated by Associated Chamber of Commerce and Industry of India that the bilateral trade could grow to US $\$ 150$ billion by 2012 (Mawdsley and McCann, 2010). One of the main reasons for the 
increased economic interrelationship could be attributed to the rapid growth of the private sector and the support from India and African governments. In line with this, India's prime minister, Mr. Singh unveiled at the India-Africa summit increased commitments that would more than double Indian credit lines in Africa, from US $\$ 2.5$ billion to US $\$ 5.4$ billion by 2008-2009 (Johnson, 2008). The summit also resulted in adoption of two documents: the India-Africa Framework for Cooperation Forum and the Delhi Declaration. The Framework for Cooperation lists areas for cooperation, such as economic, political, scientific, technology, infrastructure and research among others (Kragelund, 2010).

\section{Co-operative Investment Frameworks}

In addition to economic relations, historically India has initiated several different programs to assist African nations. Modi and Shekhawat (2009) emphasize efforts by the government of India to bolster trade relationships with Africa by launching two programs: the Focus Africa program under the Export-Import (EXIM) bank, and the Go Global Policy. Focus Africa targeted 7 Sub-Saharan countries Nigeria, South Africa, Mauritius, Kenya, Ethiopia, Tanzania and Ghana accounting for 70\% of India's total trade in the region during 2000-2001, EXIM bank extended lines of credit to facilitate the trade.

Africa is also largest recipient of technical cooperation under Indian Technical and Economic Co-operation (ITEC), which was initiated in 1964 (Kragelund, 2010). Since its formation, India has spent more than US\$1 billion for such assistance (Desai, 2009). According to Mawdsley and McCann (2010), this program encompasses short-term training in areas as diverse as small and medium-scale industries, food processing, rural credit programs, as well as IT and computer skills training. ITEC also has a sister program, Special Commonwealth Assistance for Africa Program (SCAAP) which targets African countries in the Commonwealth. According to Desai, currently 15,000 students from Africa are being trained in India, while medical, higher education, engineering and various experts are present in Africa.

Continuing in its tradition of economic, political, and technical assistance to Africa, India has given unwavering support to New Economic Partnership for Africa's Development (NEPAD) projects by extending US\$200 million. It is also funding a visionary and ambitious project partnering with the AU (African Union). The Pan-African e-Network Project is meant to remove the digital divide by connecting 53 university centers, 53 hospitals in Africa with 12 super specialty hospitals and seven Indian universities via satellite, fiber optics and wireless links (Desai, 2010; Vines, 2010). India is not stopping at this; it has also started a new program, Techno-Economic Approach for Africa-India Movement (Team 9 Initiative), for the nine Francophone West African countries to enhance commercial relation with the region (Desai, 2010).

In summary, India has focused its considerable resources and capabilities on Africa. From a government standpoint, this makes sense because of historical linkages, political and economic opportunities and security concerns including keeping the sea-lanes open and countering moves made by its tradition rival China. From an Indian business standpoint, investments in Africa make sense, not only in natural resources, but also in areas of rapidly 
growing markets with growing middle classes. What is most impressive is the variety of industries that are represented. Additionally, many of these companies are family firms with patient capital, unlike many western investors.

\section{Theoretical Explanations}

\subsection{Traditional FDI Explanations}

Foreign investment can be explained by the classical and neo-classical theories of investment (Dunning and Lundan 2008). Recently, Vasyechko (2012) has applied both types of explanations to transitional economies and noted that " the main difference of transition consists in a high level of uncertainty. A high-risk business environment influences the decisions of MNCs and the patterns of FDI (p20)”. They showed that MNCs typically evaluate decisions based on host country factors and adjust their level of commitment based on the transition stage of their host nations. Thus, both classical and transition factors influence investor decisions.

For Indian firms, it is extremely important to enter the African market and have the potential to grow into a significant industrial force (Kapur and Athreye 2009). Clearly, Indian firms have several advantages including Indian governmental policies and familiarity with the African developmental issues. In Rodgerson's article "The Locational Behavior of Foreign Direct Investment: Evidence for Johannesburg, South Africa,"(Rodgerson 2009) he concludes that foreign direct invest tends to be clustered in areas where other firms are established, this due to the availability of educated labor, suppliers and legal and other support services. As previously stated, the substantial Indian population in countries like South Africa reinforces the possibility of contacts for foreign direct investment. Additionally, these firms are structurally very flexible and know how to adapt to emerging markets.

\subsection{Porter's Five Competitive Forces}

Another model that can be used to analyze and understand India's investment in Africa is Porter's Competitive Forces framework (Porter 1980). His five forces- rivalry between existing competitors, threat from new entrants, threat from substitute products, suppliers' bargaining power, and buyers bargaining power are relevant here. For instance, (Eleren and Yilmaz 2012) used this model to analyze the competitiveness of Turkish Ceramic Manufacturing firms. The bargaining power of buyers and suppliers play out in a competitive environment to influence prices and other exchange conditions. Suppliers to Indian firms (primarily other Indian firms) provide advantage in comparison to western firms, but may not to other BRICS companies. The threats to new entrants may provide the most advantage to Indian firms many of whom are either already well-established or have contacts there.

\subsection{Porter's Competitive Advantage of Nations}

Also, certain aspects of Porter's theory (1990) can explain Indian investment in Africa. Porter's explanation which looks at competitive advantage from the country standpoint can be a useful beginning point for firms to use to explore the dynamics of a new environment. 
The first portion of this interactive model is strategy, structure and rivalry. This portion of the model reflects competition between firms and also reflects the strategies and structures that work best in an industry. New companies, new technologies and new products have a major impact on incumbents in an industry. Local firms do not always have as significant disadvantage, as it might seem, when competing against seemingly more powerful external firms. For example, they may have a formal or informal institutional advantage, for example relations with the home government could result in regulations that require joint ventures.

The next portion of the model is factor conditions. Factor conditions include: not only land, labor and capital, but also advanced factors. These advanced factors are infrastructure, technology and education, which are critical so firms can access markets or well-trained workers.

Another critical component of the model is demand conditions. Demand conditions have to do with the nature of customer (customer or business firm) requirements and the strength of customer insistence on producing quality products efficiently. This inspires the firms to strive to constantly improving products and services.

In order to be effective and control cost, the model also includes related and supporting industries. These firms are critically important since they include suppliers and complementary firms that are necessary for a firm to operate successfully. Clearly, supply chain would be a crucial consideration at this point. Concerns over cost, delivery time and control are critical.

\section{Three Case Examples from Publicly Listed Companies}

One way of exploring Indian involvement in Africa is to look at some of the important (publicly listed) Indian companies that are committed to doing business in Africa and the extent of their involvement. Three well known Indian companies have been chosen: Reliance, Tata, and Bharti. Reliance has businesses in the various aspects of the natural gas and petroleum industries, polyester, plastics, chemicals and synthetic textiles (www.ril,com/html/about us/about_brands.html). Tata is in the following sectors automotive, information technology, engineering products and services, materials, services, energy, and consumer products (www.tata.com/businesses/sectors/index.aspx?sectid=aZ72PSPwpal=.

Finally, Bharti has a strong presence in the following businesses telecom, infrastructure, IT, training, retail, insurance, investment management, and fresh fruits and vegetables (www.bharti.com/wps/wcm/connect,BhartiPortal/Bharti/home/our_companies).

It is also true that each of these companies has a strong commitment to Africa as part of their strategic plans.

\subsection{Reliance}

Reliance Industries Ltd. is the largest private sector conglomerate in India and has annual sales of about US $\$ 58.5$ billion. Since petroleum is critical to this company and India's oil sources are diminishing, Africa is a logical partner since it has an abundance of untapped petroleum (factor condition). There is tremendous demand for oil in India, which creates 
opportunities for both Reliance and its African subsidiaries. These include Gulf African Petroleum Corporation (Mauritius), GAPCO Kenya Limited, Transenergy Kenya Limited, and GAPoil (Zanzibar) Limited. These subsidiaries fill the role of related and supporting firms. Reliance's strategy is to be fully integrated along the value chain.

\subsection{Bharti Enterprises}

Bharti Enterprises is an Indian business conglomerate headquartered in New Delhi. It operates across Indian and other countries specializing in many industries like telecom, software and manufacturing. Bharti subsidiaries operating in Africa include: Bharti Airtel (telcommunication service provider), Beetel Teletech Limited (innovative mobile and solutions), Conviva (mobile solutions), and Centum Learning Limited (training). Bharti provides advanced infrastructure solutions and there is substantial demand in Africa for these types of products and services. Through its subsidiaries, Bharti can provide the linkages necessary to compete in Africa. From a strategic standpoint, Bharti's goal is to become India's largest conglomerate by expanding on its businesses in telecom, financial services, retail and foods. A particularly interesting part of the strategy is the development of strategic alliances with Singtel, IBM, Ericsson, Nokia, Siemens, Walmart and Del Monte (http:www.bharti.com).

\subsection{Tata Group}

Tata Group is an Indian multinational conglomerate headquartered in the Bombay House in Mumbai, India. Tata is the largest private corporate group in India and has businesses in communications, IT, energy and chemicals.

Tata Holdings is the primary source for identifying opportunities in Africa. Some of the major companies include Tata Zambia, Tata Zimbabwe, Tata Holdings of Mozambique and Tata Ghana. Headquarters is in Johannesburg, South Africa (http://www.tata.com/company/profile.aspx?sectid=z12COLO80BI=).

\section{Discussion}

Africa and particularly southern Africa is an important target for Indian foreign direct investment. Africa is incredibly attractive in many ways. The Indian government as noted above has made a substantial commitment to developing bilateral and multilateral relationships with the African governments. Substantial and growing investments are being made working through the private sector to invest in Africa, as well as, the government developing and promoting programs to directly aid Africa.

Indian patterns of investment in Africa are different than the European colonial or Chinese patterns. This is due to the presence of a substantial Indian population is countries like South Africa and a long relationship between India and Africa. Though, as mentioned before, there is Indian government involvement, the private sector is crucially important to the success of the African-Indian relationship. The three companies, Bharti, Reliance and Tata are privately held and largely determine their strategic direction on the basis of opportunities and external challenges. As can be seen they have moved beyond the classic resource dominated types of 
strategy to strategies respond to market demand.

Since they are experienced, multinational companies, they know very well how to work with African companies using appropriate entry modes and strategies. In the long term, this should be beneficial to both African firms and the people of Africa.

Analyzing African-Indian relationships using Porter's Diamond shows that there are substantial opportunities to add value for both African and Indian firms. This will lead to more sophisticated customers and the growth of highly competent suppliers. The advanced factors of production are being put in place with the help of many external firms and nations. The three Indian firms mention above are clearly committed to extending their knowledge and expertise to African markets. For example, Bharti and Tata are critically important to Africa in helping to develop infrastructure in telecommunication and IT.

\section{Conclusion}

Africa provides governments and firms with There are tremendous opportunities and challenges depending on where you conduct business. The same cautions apply for any company going into these markets. Do market research and understand the institutional and political context in which you will be operating. Some countries like South Africa have a well-developed institutional framework, while other countries are at a much lower level of development.

India continues to have special advantages when its firms invest in Africa because of proximity and history. The growth in Africa, the access to markets, resources and skilled labor provide for substantial opportunities now and expanded opportunities in the future.

\section{References}

Banerjee, G. (2009). Suite101.com. Retrieved November 23, 2010, from suite101.com: http://www.suite101.com

Bava, U. S. (2007). New Powers For Global Change? India's role in the emerging world order. Berllin: FES Briefing paper 4.

Baynton-Glen, S. (2012). Africa-India Trade and Investment-Playing to Strengths. Global Research. Retrieved from http://www.standardchartered.com/en/resources/global-en/pdf/Research/Africa-India_trade_a nd_investment_Playing_to_strengths.pdf

Beri, R. (2005). Africa's energy potential: Prospects for India. Strategic Analysis, July-Sept., 370-394.

Broadman, H. (2008). China and India go to Africa: New deals in the developing world. Foreign Affairs, Mar/April, 95-105.

Broadman, H. (2010). What are Chinese and Indian firms doing in Africa? Retrievd from http://www.faqs.orgs/periodicals/201004/2192573131.html, April 1, 1-5.

CIA. (2011). The World Factbook. Retrieved from 
https://www.cia.gov/library/publications/the-world-factbook/geos/ha.html

Desai, N. (2009). India and Africa: A new engagement. India Quarterly: A Journal of International Affairs, 65, 413. http://dx.doi.org/10.1177/097492840906500409

Dunning, J. H., \& Lundan, S. M. (2008). Institutions and the OLI paradigm of multinational enterprise. Asia Pacific Journal of Management, 25, 573-593. http://dx.doi.org/10.1007\%2Fs10490-007-9074-z

Edwards, R. \& Jenkins, C. (2006). The economic impacts of China and India on Sub-Saharan Africa: Trend and prospects. Journal of Asian Economics, 207-225. http://dx.doi.org/10.1016/j.asieco.2006.02.002

Eleren, A., \& Yilmaz, A. (2012). Assessment of Turkish Ceramic Manufacturing Companies' Competitiveness and Compatibilities to EU in Consideration of Porter's Five Forces Model. China-USA Business Review, 11, 1502-1514

Haglund, D. (2008). Regulating FDI in weak African states: a case study of Chinese copper mining in Zambia. Journal of Modern African Studies, 46, 547-575. http://dx.doi.org/10.1017/S0022278X08003480

Henley, J., Kratzsch, S., Kulur, M., \& Tandogan, T. (2008). Foreign direct investment from China, India and South Africa in Sub-Saharan Africa: A newor old phenomenon? Helsinki: UNU-WIDER.

Johnson, J. (2008). India follows China's path with Africa overture. Retrieved November 30, 2010, from General One File: http://find.galegroup.com/gtx/printdoc.do?contentSet=IAC-Documen...

Kapur, S., \& Athreye, S. (2009). Introduction: The internationalization of Chinese and Indian firms-trends, motivations and strategy. Industrial and Corporate Change, 209-221.

Kimenyi, M., \& Lewis, Z (2011). The BRICS and the new Scramble for Africa. Retrieved from:http://www.brookings.edu/ /media/research/files/reports/2011/1/africa\%20economy\%2 0agi/01_africa_economy_agi_kimenyi_lewis.pdf

Kragelund, P. (2010). India's Africa engagement. Roskilde University: ari.

Mawdsley, E \& McCann, G. (2010). The elephant in the corner? Reviewing India-Africa relations in the new millenium. Geography Compass, 4(2), 67-171. http://dx.doi.org/10.1111/j.1749-8198.2009.00300.x

Modi, R., \& Shekhawat, S. (2009). Pambazuka News. Retrieved November 23, 2010, from Pambazuka.org: http://www.pumbazuka.org/en/category/africa_china/60030

Nevin, T. (2008, March). The Asian Connection. African Business, 340, 20-24.

Pal, P. (2008). Surge in Indian Outbound FDI to Africa: An energing pattern in Globalization? Global Studies Conference, University of Illinois, (pp. 1-15). Chicago.

Price, G. (2004). India's aid dynamics: from recipient to donor? London: Chatham House. 


\section{Macrothink}

Journal of Management Research ISSN 1941-899X 2013, Vol. 5, No. 3

Porter, M. (1990), Competitive Advantage of Nations. New York: Free Press. http://dx.doi.org/10.1002/cir.3880010112

Porter, M. (1980). Competitive Strategy. New York: Free Press. http://dx.doi.org/10.2469/faj.v36.n4.30

Rodgerson, Christian M. (2009). The Locational Behavior of Foreign Direct Investment: Evidence from Johannesburg, South Africa. Urban Forum, 20(4), 415-435. http://dx.doi.org/10.1007/s12132-009-9071-z

UNCTAD. (2007). Asian Foreign Direct Investment in Africa: Towards a New Era of Cooperation among develping countries. New York and Geneva: United Nations.

UNCTAD. (2013). Global Investment Trends Monitor. UNCTAD-Special Edition. March 25, $1-10$.

Vasyechko, O. (2012). A Review of FDI Theories: An Application for Transition Economies. International Research Journal of Finance \& Economics, 89, 118-137

Vines, A. (2010). India's Africa Engagement: Prospects for the 2011 India-Africa Forum. London: Chatham House. http://dx.doi.org/10.1080/10220460709545498

[1] http://www.idsa.in/system/files/strategicanalysis_rberi_0603.pdf 